\title{
SNOW AND ICE IN THE MONTE FITZ ROY REGION (PATAGONIA)
}

\author{
By Louis Lliboutry
}

(University of Chile)

\begin{abstract}
The Fitz Roy district, on the margin of the Patagonian ice field ("Hielo continental"), is subject to continual and very strong west winds of high humidity. Glaciers descend to a very low level. Ablation by rain plays an important part, and contributes to some surface features, such as thin vertical sheets of ice, hummocks and dirt cones (a new theory of the origin of which is given). The summits of aiguilles, always covered with glazed frost in the Fitz Roy area, are incrusted with very heavy deposits of rime in the Cerro Torre and especially in the Cerro Grande areas. This forms huge cornices and "feathered snow" to leeward.
\end{abstract}

RÉsumé. Le massif du Fitz Roy, en marge du “Hielo continental"' Patagonique, est soumis à des vents d'ouest, violents, continuels et humides. Les glaciers descendent très bas. L'ablation par la pluie joue un rôle important, et contribue à certains aspects superficiels tels que feuillets verticaux de glace, bosses de glace et cônes de boue (dont on suggère une nouvelle explication). Les sommets des aiguilles rocheuses, toujours verglacés au Fitz Roy, sont au Cerro Torre et surtout au Cerro Grande extraordinairement givrés, avec formation de gigantesques corniches et de neige "en choux-fleurs" du côté sous le vent.

Since the corrie and valley glaciers of the Monte Fitz Roy region* are more like those of the Alps than are any others in the Andes, they will be of interest to the glaciologist for purposes of comparison. In a first reconnaissance which the author made as a member of the French Alpine Expedition of $195 \mathrm{I}-52$ to this district, he was occupied with other tasks, and could only note the more striking differences between the snow and the glaciers of this region and those of the Mont Blanc range, which is well known to him. These differences are, of course, due to differences in climate.

\section{The Climate of the Fitz Roy district}

The most characteristic feature of the south Patagonian climate is the very strong and almost incessant wind, which often reaches $100 \mathrm{~km}$. $/ \mathrm{hr}$. on the crests, with gusts of $150-180 \mathrm{~km}$. Not only fresh snow but even stones are blown off ridges and summits. Aeolian pot-holes $15 \mathrm{~cm}$. deep and $30-40 \mathrm{~cm}$. wide were observed in the Fitz Roy granodiorite, a rock as hard as the protogine of the Chamonix aiguilles. During two months in the summer of $195^{2}$ there were only five days when the wind dropped to a gentle breeze on the summits. This occurrence followed a southsouth-westerly warm wind, without variation of the barometer. An abrupt fall of the barometer foretold a renewal of the two main winds: the westerly wind, cool and very damp, bringing rain to the whole district, and the north-westerly wind, colder but only bringing showers. The temperature in summer is cool, but not cold (mean temperature $1 \mathrm{I}^{\circ} \mathrm{C}$. at a height of $75^{\circ} \mathrm{m}$.), and diurnal variations are small (mean range $10.8^{\circ} \mathrm{C}$. at the same place).

The second feature of the climate is that precipitation, which is distributed equally throughout the year, varies enormously from the Pampa $(0 \cdot 30 \mathrm{~m}$./ann.) to the Hielo continental (approximately $5 \mathrm{~m}$./ann.). At the Estancia Madsen (Rio de Las Vueltas valley) precipitation is $0.8_{5}$ $\mathrm{m}$./ann., in the Rio Blanco valley it is probably $1.50 \mathrm{~m}$./ann., and on the west side of the Fitz Roy region probably $3 \mathrm{~m}$./ann. This variation, in conjunction with the differing degrees of exposure to westerly winds, gives rise to many microclimates. For example, from 9 January to 9 February there was only one complete day in the Rio Blanco valley on which the sky was wholly overcast, but there were nineteen such days on the other side of Monte Fitz Roy.

Differences between seasons are slight, in spite of the fact that the region is on the forty-ninth parallel. Generally in winter the winds are less strong and the sky is less cloudy. But, as the people of these regions say, "All the seasons can be observed in a single day." In spite of this variability of the weather, electric storms and hail are practically unknown here.

* See the author's previous paper in fournal of Glaciology, Vol. 2, No. 13, 1953, p. 168-72, and footnote on p. 169. 


\section{CORRIE GLACIERS WITH ALPINE FEATURES}

A detailed map of the Fitz Roy region is given here for the first time (Fig. I, below) The core of this region is a stock of granitic rocks with an area of $45 \mathrm{sq}$. km. There are two ridges running north-south, an eastern ridge culminating at Monte Fitz Roy (344I m.), and a western

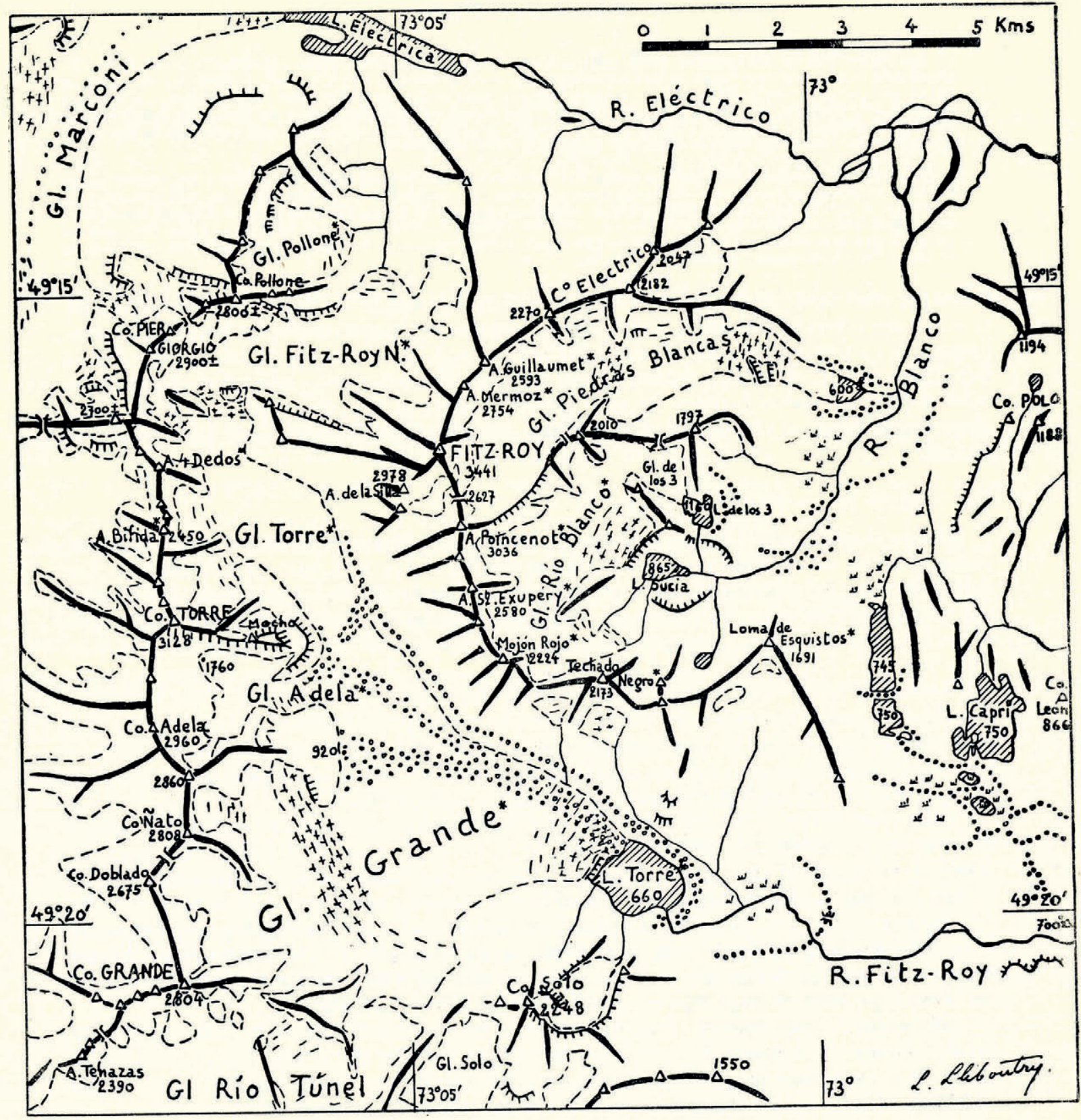

Fig. I. The Monte Fitz Roy region. Names not yet officially accepted are marked with an asterisk 
ridge, culminating at Cerro Torre $(3128 \mathrm{~m}$.). The latter ridge, except at its northern end, borders the Hielo continental (see map in the author's previous paper in this fournal, p. 17I). Neither ridge falls below $2000 \mathrm{~m}$., whereas the average height of the Hielo continental is $1500 \mathrm{~m}$., that of the middle valley, $1000 \mathrm{~m}$., and that of the eastern Rio Blanco valley, $700 \mathrm{~m}$. Owing to the heavy precipitation and the prevailing cloudiness, the middle valley is entirely occupied by glaciersthe Torre Glacier, flowing south, and the Fitz Roy North Glacier, higher and steeper, flowing north.

There is as yet no agreement concerning the names of the glaciers and terminal lakes, and those given here must be regarded as unofficial. In particular, the three glaciers referred to here by the names of Torre, Adela and Grande have sometimes been referred to collectively by the

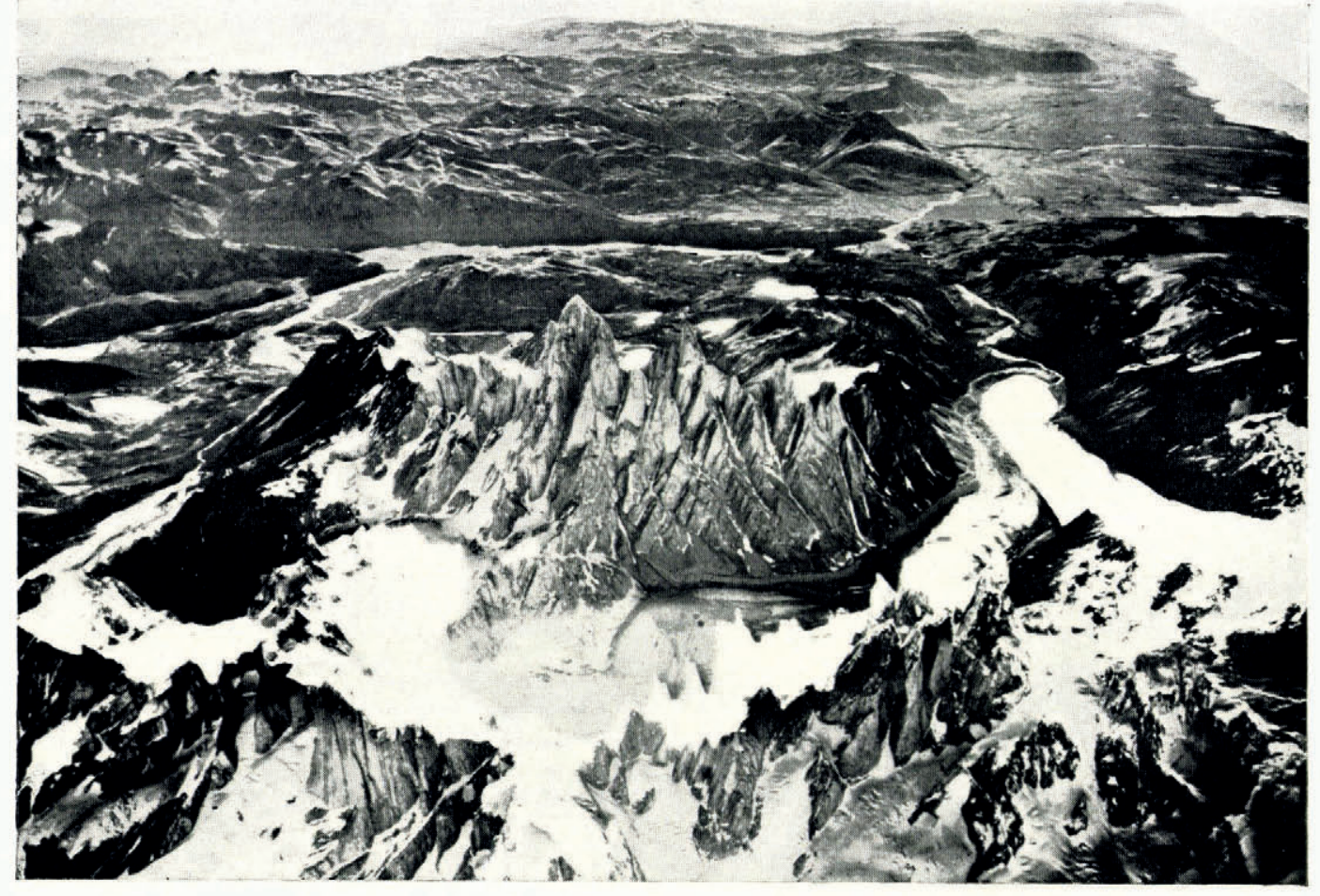

Fig. 4. General view of the Monte Fitz Roy region from the west, taken from an altitude of $6000 \mathrm{~m}$. over the "Hielo Continental." In the distance lakes San Martin (left) and Viedma (right); the distance between the two is $42 \mathrm{~km}$. In the middle Rio de las Vueltas, and a region formed by an arm of the "Hielo Continental" during the Ice Age. The peak is that of Monte Fitz Roy (344I m.) The visible face is $2000 \mathrm{~m}$. high. In the foreground the Torre Glacier, Cerro Pier Giorgio (the large wall) on the left, and Cerro Torre (covered with rime and snow) on the right

name of Fitz Roy Glacier, although they have quite different features and none of them receives ice from the slopes of Monte Fitz Roy.

On the eastern side, the Piedras Blancas is a typical alpine glacier, with a corrie (rounded by a great bergschrund, open at the end of summer) from which flows an ice stream, twice broken into seracs and re-formed again. The glacier ends in a lake at about $600 \mathrm{~m}$. above sea-level. The blue bands, which are almost vertical and very convex on a rocky bed $200 \mathrm{~m}$. from the front, are at an angle of 45 degrees or less from horizontal, and are rectilinear at the front, where the glacier is probably afloat (Fig. 2, p. 258). 

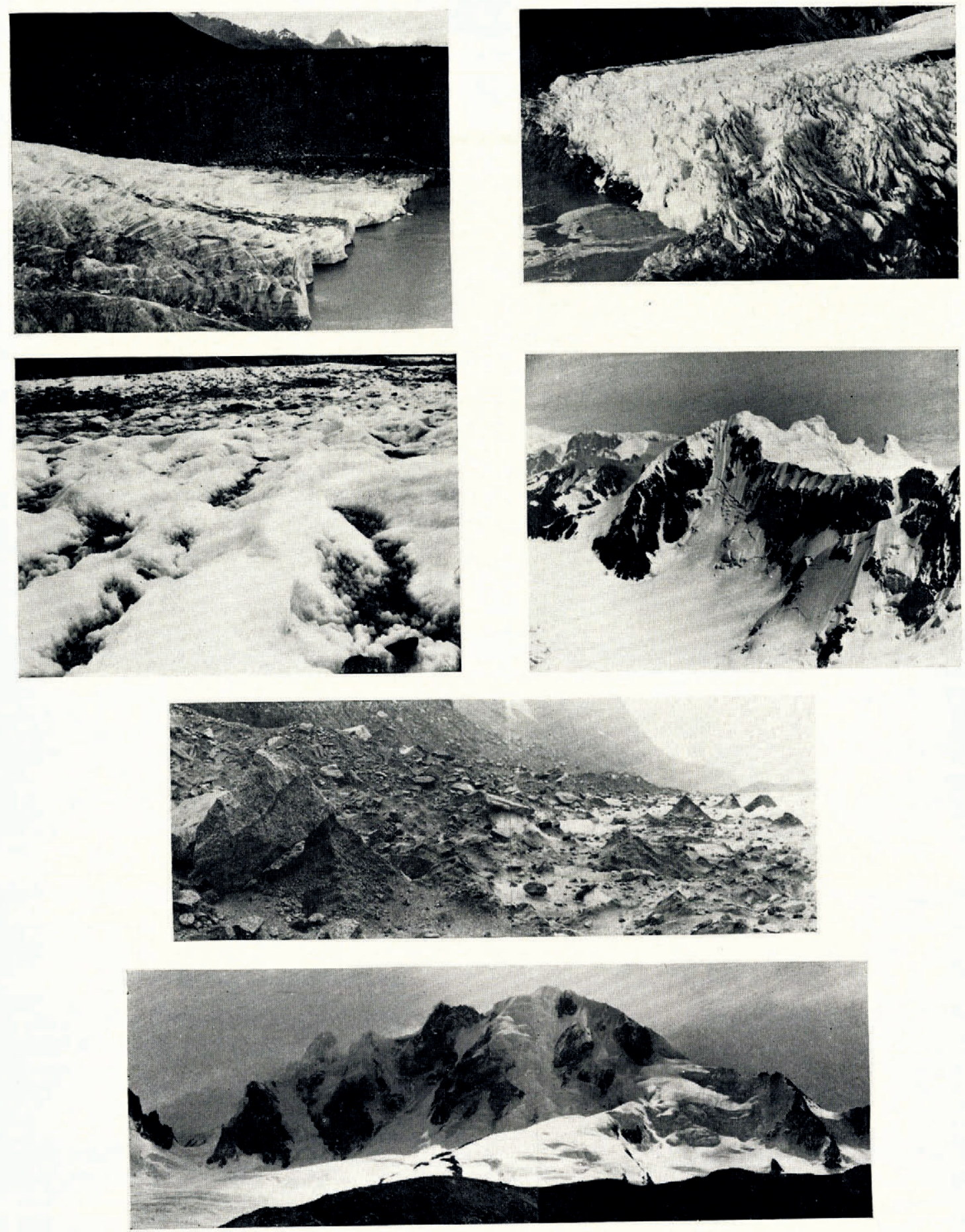

Fig. 2 (top line left). Front of the Piedras Blancas Glacier

Photographs by L. Lliboutry

Fig. 3 (top line right). Front of the Grande Glacier

Fig. 5 (second line left). Surface of the Torre Glacier after rain

Fig. 6 (third line). Dirt cones on the Adela Glacier

Fig. 9 (bottom line). Cerro Grande, south side. Height above the glacier $500 \mathrm{~m}$.

Fig. Io (second line right). Cerro Grande seen from the north-east. The largest "mushroom" of snow is $80 \mathrm{~m}$. high. On the left Cerro Murallón 
On these eastern slopes the firn line was at about $125^{\circ} \mathrm{m}$. at the end of the summer of $195^{2}$, which farmers considered a dry one. During these two summer months snow fell on three occasions at as low a level as $1100 \mathrm{~m}$. The snow was everywhere exceptionally wet and heavy, firmly catching the leg or even the handle of the ice axe. Fortunately the glaciers were not steep enough to give rise to avalanches, which would have been particularly dangerous.

The Grande Glacier receives a much greater amount of nourishment. Its bergschrund, although traceable, was filled with snow at the end of the summer (Fig. 10, p. 258). The velocity of this glacier is certainly high, as it has insignificant surface moraines, and its front is extensively cracked in spite of the regularity of its bed. Dr. Guth, a well-known "Andinist" of Buenos Aires, who spent many days beside Laguna Torre, estimated the rate of movement to be $\mathrm{I} \mathrm{m}$. a day. The front of the glacier is characterized by some vertical sheets of ice (Fig. 3, p. 258), caused by numerous transverse crevasses, and having edges sharpened by melting (principally due to rain). This front is similar in appearance to that of the Viedma Glacier.

\section{The Torre Glacier}

This glacier is deeply entrenched between Cerro Torre and Monte Fitz Roy (Fig. 4, p. 257). The gentle gradient and the absence of crevasses, together with the low altitude, explain the existence of a morass of snow over the ice in summer with a depth of about $\mathrm{I} \mathrm{m}$. at its centre. The velocity of the Torre, like that of the Adela Glacier, must be very small, as the lower parts of both glaciers are thrust aside against the left bank by the Grande Glacier and are covered with morainic debris. This velocity can be estimated from the movement of a large rock fall which originated from Monte Fitz Roy, crosses the whole glacier, and is clearly shown on an aerial photograph taken in 1945. During the last seven years its upper end has advanced $300-400 \mathrm{~m}$. and its lower end $600-700 \mathrm{~m}$., a rate of movement of $\mathrm{r}^{-2} 5 \mathrm{~cm}$. per day.

The exact source of this fall is uncertain, since weathering of the rocks (perhaps caused by wind-driven ice crystals) is very rapid on the west face of Monte Fitz Roy, and in a few years would obliterate the scar left there. The fall seems to be from the Aguja de La Silla, r700 m. up the glacier, and therefore should have occurred about twenty-four years ago. As this rock fall now reaches a height of $5^{-8} \mathrm{~m}$. above the surface of the glacier, the superficial ablation of the ice at $1000 \mathrm{~m}$. may be $20-30 \mathrm{~cm}$. a year. Such a low rate of ablation is not surprising. The sky is almost always overcast, and the ice receives only about $5^{\circ}$ hours of direct sunlight in a year, so that not more than perhaps $10 \mathrm{~cm}$. of ice can be melted by the sun. The same amount of melting can be caused by $\mathrm{I} \mathrm{m}$. of rain at a temperature of $8^{\circ} \mathrm{C}$., a rate of precipitation which does exist in summer, when the ice is bare.

Thus on the Torre Glacier melting caused by rain is as important as melting caused by the sun, and affects different localities (hollows in the ice instead of slightly dirty ice). The appearance of the surface of the glacier is affected accordingly. When the author first visited the glacier, after a sunny week, the surface was similar to that of the Mer de Glace-white ice, slightly dirty, roughly uniform, and scaling superficially. When he next visited the glacier, after several days of rain, its surface was completely altered (Fig. 5, p. 258); there were little hummocks of white ice, one or two metres broad, coated with perfectly clean glazed frost, and between them the ice was riddled with small vertical holes a few centimetres broad and $5-20 \mathrm{~cm}$. deep, generally with a pebble at the bottom of each, never with sand or glacial mud. In some places, holes had coalesced at the surface, leaving groups of little pinnacles in the ice. This alteration can be accounted for by the action of both rain (which cleans the hummocks, washes away the dirt and deepens the holes) and sun (which initiates the holes).

Fig. 5 must be compared with the photographs on p. 376 and 377 of the Fournal of Glaciology, Vol. I, No. 7, 1950, showing ice hummocks on the Gorner Glacier and ice pyramids on the Baltoro Glacier. The warm monsoon rains would appear to play an important part in the shaping of these ice pyramids.

$17^{*}$ 
The diRT CONES of the Adela Glacier

Adela Glacier, at the foot of the east wall (1200 m. high) of Cerro Adela, is of an alpine type. The lower part of this glacier is separated from the Torre Glacier by a supraglacial moraine of light grey granodiorite originating from Cerro Torre. On this side of the Adela Glacier there are some crevasses, many elliptical holes full of water several metres deep, and many dirt cones about one metre high (Fig. 6, p. 258). Most of these dirt cones had a wide depression at the top; only three out of twenty had instead a small earth-filled crevice, $5^{-1} 5 \mathrm{~cm}$. deep. One-third of the dirt cones had a large stone at the foot; one-third were in lines running north-south, at right angles to the crevasses, which there run east-west. In view of the above-mentioned facts, it would appear that these dirt cones generally have a different origin from those studied by Swithinbank, 1 which, he suggested, develop from deposits in the bottom of a crevasse or hollow. It seems probable that the dirt cones of the Adela Glacier develop from boulder-capped ice pinnacles (small glacier tables) from which the stone has slipped on the north side (the glacier being in the southern
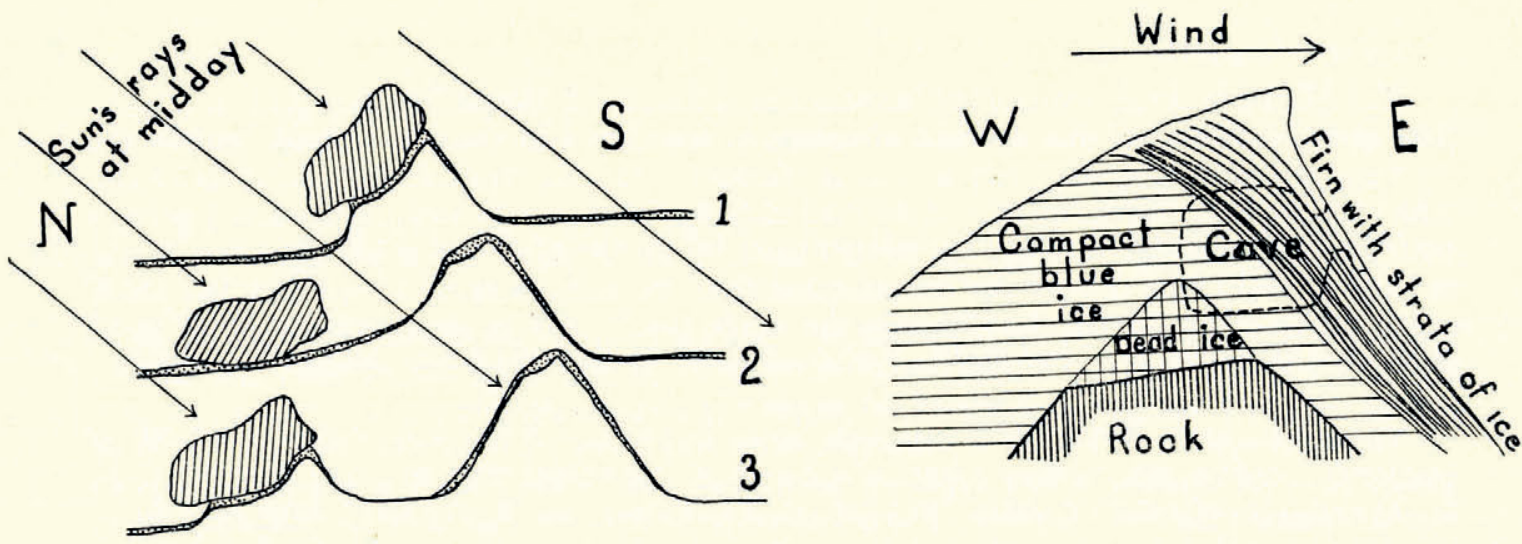

Fig. 7 (left). Formation of dirt cones

Fig. 8 (right). Schematic section of the small glacier on the saddle of Monte Fitz Roy

hemisphere). (In Fig. 6 it will be seen that such a boulder has fallen half-way down the nearest cone.) Rain has then washed down dirt from the surrounding area, and has shaped the cone. The same stone could give birth to several cones in a line, each time moving northward by solifluction while the cone moves southward, its northern side continuing to melt. Fig. 7 (above) is a diagrammatic representation of this process. The same process is visible on the right of Fig. 6 , which shows a large cone, a small cone and a stone perched on the glacier in perfect alignment. The process ends when, in its motion northward, the stone falls into a crevasse.

Dirt cones have been photographed on the Upsala Glacier by De Agostini (see author's previous paper in this fournal), and on the Viedma Glacier by Kölliker. ${ }^{2}$

\section{The small glacier on the saddle of Monte Fitz Roy}

It was not possible to pitch a tent in the Patagonian wind, nor to erect an igloo, since winddriven ice crystals would soon have eroded and destroyed it; the upper camps therefore consisted of caves dug in the ice or in the firn.

Camp I at $2000 \mathrm{~m}$. and Camp 2 at $2375 \mathrm{~m}$. were dug in the firn, on the lower side of bergschrunds. The firn contained some bands of blue compacted ice parallel to the surface, $2 \mathrm{~cm}$. thick and about $\mathrm{I} \mathrm{m}$. apart; these may separate annual snowfalls.

Camp 3 was dug at $2770 \mathrm{~m}$., in a small saddle-shaped asymmetrical glacier (very steep on the east, gently sloping on the west), bestriding the ridge at the foot of the south end of Monte 
Fitz Roy (Fig. 4). The cave had to be dug on the steep eastern leeward slope, as the gusts of wind brought on painful compression and decompression of air in a windward cave. No snow can stay on the ridge, and the windward slope, in spite of being $1500 \mathrm{~m}$. above the firn line, was of pure blue ice, without any covering of snow. On the eastern slope there was $\mathrm{r} \cdot 50 \mathrm{~m}$. of snow compacted by the wind and more or less befirned, with about twelve strata of ice $2 \mathrm{~cm}$. thick parallel to the slope (Fig. 8, p. 260). Except for one stratum which contained many crystals of black biotite, the snow and the ice were very clean. Kinzl and Schneider, ${ }^{3}$ who observed a similar stratification in the Cordillera Blanca of Peru, suggested that it represents successive snowfalls, but without advancing any proof. At the bottom of the cave, probably just on the ridge, there were great crystals of dead ice containing impurities.

When the warm south wind blows, great quantities of ice crystals, $1.5 \mathrm{~cm}$. in diameter, pour down the eastern slope from the uppermost strata.

The curious strip of ice perched on the ridge between Cerro Torre and the Mocho is probably similar to the ice of the saddle.

\section{GLAZED FROST, RIME AND "FEATHERED SNOW"}

The two climbers of Monte Fitz Roy found thick glazed frost from $3000 \mathrm{~m}$. upwards. This frost, which persists throughout the year, is derived from wet snow, thickly deposited over a leeward rocky wall, then momentarily melted by the sun and finally frozen.

The sun very rarely strikes the three needles of Cerro Torre and the five needles of Cerro Grande, on the border of the Hielo continental, since these are almost always enveloped in cloud. The tops of these needles are heavily mantled by rime and wind-blown snow (Fig. 9, p. 258). Both rime and snow produce huge cornices of $10-20 \mathrm{~m}$. on the western needles of Cerro Grande, giving them the appearance of fantastic mushrooms (Fig. 1o, p. 258). Neither melting nor firnification appears to take place, so the layer of ice under the compacted snow may be thick but rather dead.

On the south-east and north-east sides, that is to leeward, under the cornices, the snow undoubtedly exhibits a feature ("feathered snow") sometimes observed at high altitudes, e.g. on Alpamayo (Cordillera Blanca of Peru) at $6000 \mathrm{~m}$. and on Annapurna in the Arête des Choux-fleurs, at $6500 \mathrm{~m} .{ }^{4}$ Here the altitude is only $2700 \mathrm{~m}$., but wind and snowfall are as important as altitude. This confirms the explanation of "feathered snow" (rime growing upwards on snow cones) * given by Kinzl and Schneider ${ }^{3}$ - that it is due to whirlwinds on the leeward side of a ridge. It will be of great interest to reach at least the foot of these needles, which nobody has yet seen from a distance of less than $5 \mathrm{~km}$.

\section{ACKNOWLEDGEMENTS}

I am glad to thank Mr. G. Seligman and Prof. A. Cailleux, for their good advice. I am moreover grateful to the Government of the Argentine Republic, which took so much interest in the Expedition and granted us invaluable facilities.

$M S$. received 20 fune 1952

\section{R E F E R E N C E S}

1. Swithinbank, Charles. The origin of dirt cones on glaciers. Fournal of Glaciology, Vol. x, No. 8, 1950, p. 46 r-65.
2. Kölliker, Alfred. In den Einsamkeiten Patagoniens. Stuttgart, Strecker und Schröder, r926.
3. Kinzl, Hans, and Schneider, Erwin. Cordill

3. Kinzl, Hans, and Schneider, Erwin. Cordillera Blanca. Innsbrück, Universitäts Verlag, 1950.

4. Herzog, Maurice, and Ichac, Marcel. Regards vers l'Annapurna. Grenoble, Arthaud, 1951.

\footnotetext{
* The description of "feathered snow" given here by the author tallies closely with the cones of mixed rime and snow illustrated and described in Seligman, G., Snow Structure and Ski Fields, Macmillan, 1936, p. 88-94, and called
"Fog Deposit."-Ed.
} 